\title{
Web-based E-diagnostic for Digestive System Disorders in Mumans using the Demster Shafer Method
}

\author{
Eka Ayunda Prameswari \\ Faculty of Information and \\ Communication Technology \\ - National University
}

\author{
Agung Triayudi \\ Faculty of Information and \\ Communication Technology \\ - National University
}

\author{
Ira Diana Sholihati \\ Faculty of Information and \\ Communication Technology \\ -National University
}

\begin{abstract}
Digestive system disorders are dangerous diseases. Lack of awareness of public health is still low, life habits, behavior and mindset that want to live practically, a means of delivering information about diseases that are still lacking, and the lack of medical personnel is a problem, therefore an expert system application is needed to diagnose disease on the web-based digestive system. By providing certainty in the form of a percentage, then using the calculation through symptoms chosen by the user of each symptom has a density value, the density value is obtained from the results of interviews with doctors. Web-based E-Diagnostics for digestive system disorders uses the Dempster Shafer method which is expected to help users by providing information on disease diagnosis and solutions that can be done to help cure it, the Dempster Shafer Method has the ability to provide a high level of accuracy or certainty, which method this has characteristics that are in accordance with the way an expert thinks. This web-based expert system application will display symptoms that can be selected by the user to get the final results in the form of rapid disease diagnoses and suggestions for prevention in order to find out information in the form of diagnoses of diseases of the digestive system. Based on the calculation of accuracy that has been done in this study, it can be seen that the Dempster Shafer Method is the method that has the highest value with $85 \%$ confidence compared to the Certainty Factor Method with a value of $60 \%$.
\end{abstract}

\section{Keywords}

Expert System, E-Diagnostic, Digestive, Dempster Shafer.

\section{INTRODUCTION}

With the development of digital technology today, it encourages the use and utilization of these technological developments widely in various fields, especially medicine. In its very rapid development as it is now, computers not only function as image processing or words, but can function as an expert or expert. The implementation is also in various fields of medicine, one of which is to diagnose a human digestive disease based on the symptoms experienced. But in its utilization, the system is not yet well known by the wider community so that the community must come directly to the hospital to check for what diseases are suffered based on their symptoms.

Based on the above constraints an expert system is needed to diagnose digestive system disorders in humans. The system

used in this study is a web-based expert system using the calculation of the Dempster Shafer method that can be accessed by the public. Therefore the author took the title "Expert System for Diagnosing Digestive System Disorders in Humans with the Dempster Shafer Method". It is hoped that with this expert system, there will be no diagnostic error and make it easier for users to know the diagnosis of disease, the definition of disease, the causes and also solutions to healing earlier in disorders of the digestive system [1-3].

Dempster Shafer has the ability to prove the accuracy of the calculation theory based on the values of belief and plausibility, belief (Bel) is a measure of the strength of evidence in supporting a set of propositions and Plausability (Pls) will reduce the level of certainty of evidence. The Dempster Shafer method can be measured based on the diagnosis of the disease obtained with the highest percentage value [3-8].

The purpose of this study is to develop an E-diagnostic application that can diagnose digestive system disorders in humans using the calculation of the Dempster Shafer method that can be useful for users or the public in diagnosing digestive system disorders using expert system applications with the web-based Dempster Shafer method. To perform an initial diagnosis of digestive system disorders, the database used is PHP and Mysql. It is expected that the application that will be created can help in providing information and solutions.

\section{RESEARCH METHODS}

- Data Collection

In this research phase, data collection will be carried out relating to the research conducted, such as the types of diseases in the human digestive system, symptoms of disease symptoms, and other data needed in accordance with the problem at hand. All stages of the process are obtained from interviews, and literature studies.

\section{- Analysis of System Requirements Hardware (Hardware)}

Hardware is used to support program processing. Consists of input units, data processing and output units. In the Expert System to Diagnose Web-Based

Digestive System Disorders in Humans, computers are used with the following specifications:

a) LAPTOP-5B11MN3H

b) 4 Gigabyte Ram

c) Processor: AMD A9-9435 Radeon R5.

- $\quad$ Software (Software)

The software used in this Expert System for Diagnosing WebBased Digestive System Disorders in Humans is:

a) Windows 10 Pro 64-bit as an operating system

b) Xampp as a developer application based on php and mysql

c) Google Chrome as a browser application

- System Design 
The system created is Website-based and the programming language used by PHP MySql, for designing websites that will be calculated later on the website. The design of this system is to find out the specifications of the computer that runs the program and what programs are needed. In the study will practice directly the results of the analysis that aims to test the truth of the process carried out manually and with the program. At this stage the design of the system will be carried out. The steps taken in designing this system can be described by the system flowchart, the Dempster shafer method Flowchart, and the class diagram.Dempster Shafer has the ability to prove the accuracy of the calculation theory based on the values of belief and plausibility, belief (Bel) is a measure of the strength of evidence in supporting a set of propositions and Plausability (Pls) will reduce the certainty level of evidence. The Dempster Shafer method can be measured based on the diagnosis of the disease obtained with the highest percentage value. Stages of research that will be discussed in the Expert System for Diagnosing Digestive System Disorders in Humans with the Dempster Shafer.

1. System Flow Next is the flowchart system of applying the method.

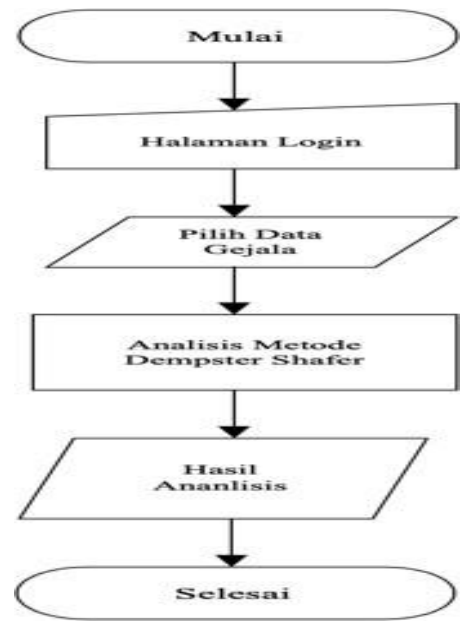

Figure 1. Flowchart System

The flow of system usage in general is to directly open the login page. Then the user can immediately open the main page on the system and the user can directly choose the geja la disease experienced. Based on the selection of these symptoms, the system performs an analysis with the Dempster Shafer method, so that it will produce conclusions on diagnosing digestive system disorders in humans.

2. Dempster shafer flowchart

The following is an overview of the system flow (flowchart) from the application of the dempster shafer method.

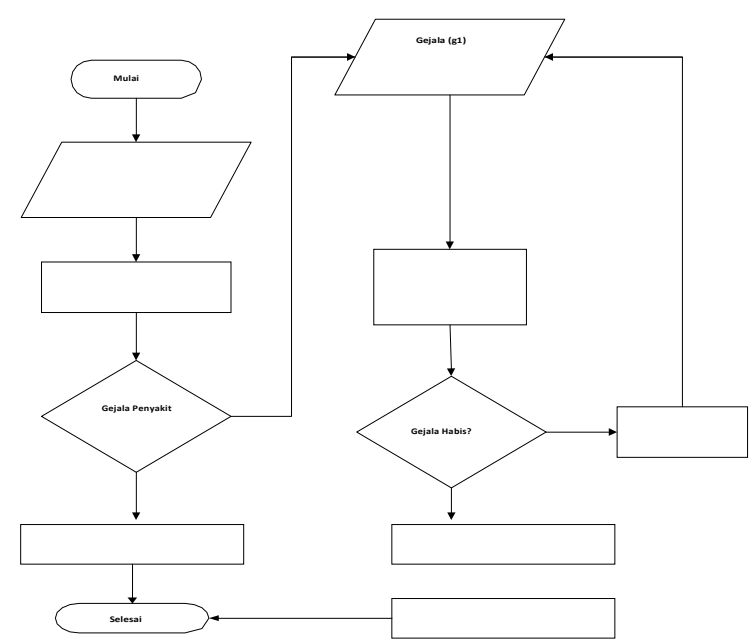

Figure 2. Flow of the dempster shafer method

The initial calculation by entering the value of density and sickness will be stored in the database. Users enter fact symptoms that occur in the digestive system. Then the application will be matched in the database. So that it will get the results of cat disease and the value of density, can be calculated with the value of belief and plausibility. After the value is obtained, if the value is 1 , then from the results of the name of the disease according to these symptoms have the highest belief value is probably the solution. If the value turns out to be included more than 1 , then the results of the disease and the value of belief plausibility to the first symptom are stored. For the second symptom, the first symptom is done and the results are stored. After getting the value of these two symptoms, a combination of symptom calculation 1 and 2 can be done to find the value of density 3. The result of the combination of two symptoms is likely to get the third density value. If there are no other symptoms, then the highest possible outcome is close to one which will be the solution [35].

3. Class Diagram

The following expert system diagram diagram can be seen in the picture below.

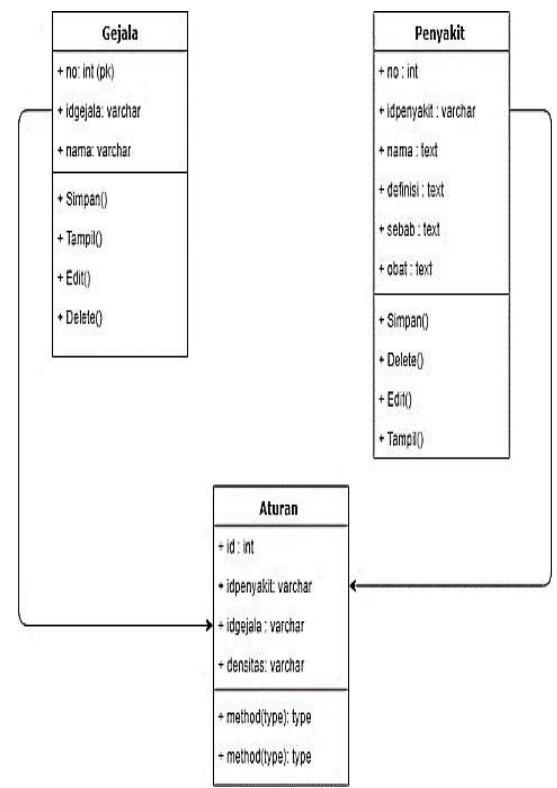

Figure 3. Class Diagram 
In figure 1 above, it consists of three classes, namely the symptom class, the disease class, and the class detail rule with the description:

1. Symptom tables related to rule tables

2. Disease tables related to rule tables.

\section{Analysis Calculation Demster Shafer}

Dempster Shafer Analysis Search method that starts with a set of facts about a symptom that is given by the user as input system, then carried out by tracking calculations using the Dempster Shafer method and Certainty Factor until the ultimate goal is diagnosing digestive system disorders in humans and belief value [3].

\section{RESULTS AND DISCUSSION}

The data analysis stage is the most important stage in the research of a system, because at this stage later the performance evaluation will be carried out, identification of existing problems, system design and steps needed for the desired design until the analysis is expected. The following are data on diseases and symptoms of cats that have been obtained from experts.

At this stage calculations are carried out using the DempsterShafer theory, which is written in a [Belief, Plausibility] interval. Belief (Bel) is a measure of evidence strength in supporting a set of propositions. If it is worth 0 then identify that there is no evidence, and if it is worth 1 indicates certainty. Plausability $(\mathrm{Pl})$ is denoted as $\mathrm{Pl}(\mathrm{s})=1-\mathrm{Bel}(-\mathrm{s})$. Plausability is also worth 0 to 1 . If we are sure of $-\mathrm{s}$, it can be said that Bel $(-s)=1$, and PL $(-s)=0$. In the Dempster-Shafer theory we recognize the frame of discernment denoted by $\theta$. This frame is a speaker universe from a set of hypotheses [4].

With the Dempster Shafer formula as follows: $\mathrm{m} 1 \oplus \mathrm{m} 2(\mathrm{Z})=\Sigma \rrbracket(\mathrm{X} \cap \mathrm{Y}=\mathrm{Z} @ 1-\mathrm{P} @)$ 带 $\llbracket$

$\mathrm{m} 1(\mathrm{X}) \mathrm{m} 2(\mathrm{Y}) \rrbracket[1]$

$\mathrm{m} 1 \oplus \mathrm{m} 2(\mathrm{Z})=$ mass function of evidence $(\mathrm{Z})$

$\mathrm{m} 1(\mathrm{X})=$ mass function of evidence $(\mathrm{X})$

$\mathrm{m} 2(\mathrm{Y})=$ mass function of evidence $(\mathrm{Y})$

$\bigoplus=$ direct sum operator

From the calculation of the formula above, the required data is in the form of rules or symptoms, attributes or diseases, which can produce a relation in the research of digestive system disorders in humans as follows.

Table 1. Symptom data Information

\begin{tabular}{|c|c|c|}
\hline No. & Kode Gejala & Gejala \\
\hline 1 & G1 & Nyeri pada dada \\
\hline 2 & G2 & Nyeri di perut \\
\hline 3 & G3 & Batuk Kering \\
\hline 4 & G4 & Batuk Berdahak \\
\hline 5 & G5 & Demam \\
\hline 6 & G6 & Sakit Kepala \\
\hline 7 & G7 & Mual \\
\hline 8 & G8 & G9 \\
\hline 9 & & \\
\hline
\end{tabular}

\begin{tabular}{|c|c|c|}
\hline 10 & G10 & Muntah \\
\hline 11 & G11 & Mulas \\
\hline 12 & G12 & Cegukan \\
\hline 13 & G13 & Perut terasa kembung \\
\hline 14 & G14 & Lidah terasa seperti berlendir \\
\hline 15 & G15 & Terasa asam pada mulut \\
\hline 16 & G16 & Kehilangan nafsu makan \\
\hline 17 & G17 & Berat badan menurun \\
\hline 18 & G18 & Terasa sesak saat bernafas \\
\hline 19 & G19 & Sendawa tiada henti \\
\hline 20 & G20 & Nafas berbau tidak sedap \\
\hline 21 & G21 & Tubuh terasa lemas \\
\hline 22 & G22 & Mulut terasa kering \\
\hline 23 & G23 & Terasa haus berlebihan \\
\hline 24 & G24 & Tinja berlendir \\
\hline 25 & G25 & Urine menjadi sedikit/berwarna gelap \\
\hline 26 & G26 & Cepat merasa kenyang \\
\hline 27 & G27 & Tinja berwarna gelap \\
\hline 28 & G28 & Terasa Kram pada perut \\
\hline 29 & G29 & BAB berdarah \\
\hline 30 & G30 & Tidak bisa buang gas (kentut) \\
\hline
\end{tabular}

In table 1 above are symptoms based on the knowledge or rules obtained from experts, these symptoms are symptoms that are felt in digestive system disorders.

Table 2. Disease Based On Knowledge Information:

\begin{tabular}{|c|c|l|}
\hline No. & Kode Penyakit & \multicolumn{1}{|c|}{ Nama Penyakit } \\
\hline 1 & P1 & Penyakit Asam Lambung \\
\hline 2 & P2 & Penyakit Magh Kronis \\
\hline 3 & P3 & Penyakit Diare \\
\hline 4 & P4 & $\begin{array}{l}\text { Penyakit Gastritis (Peradangan } \\
\text { Dinding Lambung) }\end{array}$ \\
\hline 5 & P5 & Penyakit Radang Usus \\
6 & P6 & Penyakit Keracunan Makanan \\
\hline 7 & P7 & Penyakit Usus Buntu \\
\hline
\end{tabular}

In table 2 above is a disease based on knowledge or rules obtained from experts, the disease is a disease caused by a disruption of the digestive system. From the data rule and the attributes above, it can be used as a decision table for relations with the percentage end value that uses the Dempster Shafer calculation. 
Table 3. Data on the relation of symptoms to digestive system disorders in humans

\begin{tabular}{|c|c|c|c|c|c|c|c|c|c|}
\hline \multirow{2}{*}{$\begin{array}{l}\text { Kode } \\
\text { Gejialla }\end{array}$} & \multicolumn{8}{|c|}{ Bercalit } & \multirow{2}{*}{$\begin{array}{c}\begin{array}{c}\text { Hasil } \\
\text { Berchitungenn }\end{array} \\
\text { DS }\end{array}$} \\
\hline & P1 & P2 & P3 & P4 & P5 & P6 & P7 & Ket Bensyalijt & \\
\hline Gl & $\checkmark$ & & & & & & & pl & 0.2 \\
\hline G2 & $\checkmark$ & & & $\sqrt{ }$ & & & & $\mathrm{p1}, \mathrm{p4}$ & 0.4 \\
\hline G3 & & & & & $\checkmark$ & & & p5 & 0.3 \\
\hline G4 & & $\checkmark$ & & $\sqrt{ }$ & & $\checkmark$ & & $\mathrm{P} 2, \mathrm{p4}, \mathrm{P} 6$ & 0.6 \\
\hline G5 & $\checkmark$ & & & & & & & pl & 0.2 \\
\hline G6 & & & & $\checkmark$ & & & & p4 & 0.3 \\
\hline G7 & & & $\checkmark$ & & & & $\checkmark$ & $\mathrm{p3}, \mathrm{p}\}$ & 0.5 \\
\hline G8 & & & $\checkmark$ & & & $\checkmark$ & & $\mathrm{p3}, \mathrm{p} 6$ & 0.4 \\
\hline$G 9$ & & $\sqrt{ }$ & & $\sqrt{ }$ & & $\checkmark$ & $\checkmark$ & $\mathbf{p} 2, \mathrm{p} 4, \mathrm{p} 6, \mathbf{p} 7$ & 0.8 \\
\hline G10 & & & & $\checkmark$ & & $\checkmark$ & & $\mathrm{P} 4, \mathrm{p} 6$ & 0.4 \\
\hline Gl1 & $\checkmark$ & & & & $\checkmark$ & & & $\mathrm{p} 1, \mathrm{p} 5$ & 0.5 \\
\hline $\mathrm{G} 12$ & & & & $\checkmark$ & & & & p4 & 0.2 \\
\hline $\mathrm{G} 13$ & $\checkmark$ & $\checkmark$ & & $\checkmark$ & $\checkmark$ & & $\checkmark$ & $\mathrm{p} 1, \mathrm{p} 2, \mathrm{p} 4, \mathrm{p} 5, \mathrm{p} 7$ & 0.9 \\
\hline G14 & & $\checkmark$ & & & & & & $\mathrm{p}_{2}$ & 0.2 \\
\hline G15 & $\checkmark$ & & & & & & & pl & 0.2 \\
\hline G16 & $\sqrt{ }$ & & & $\checkmark$ & $\sqrt{4}$ & & $\checkmark$ & P1,p4,p5,p7 & 0.8 \\
\hline G17 & & $\checkmark$ & $\checkmark$ & & $\checkmark$ & & & P2, $\mathrm{p3}_{3}, \mathrm{p} 5$ & 0.7 \\
\hline G18 & $\sqrt{ }$ & & & & & & & pl & 0.2 \\
\hline G19 & $\sqrt{ }$ & $\checkmark$ & & & & & & $\mathrm{p} 1, \mathrm{p}_{2}$ & 0.4 \\
\hline $\mathrm{G} 20$ & & $\checkmark$ & & & & & & $\mathrm{p} 2$ & 0.3 \\
\hline G21 & & $\checkmark$ & $\checkmark$ & & & $\checkmark$ & & $\mathbf{p} 2, \mathrm{p} 3, \mathbf{p} 7$ & 0.7 \\
\hline $\mathrm{G} 22$ & & & $\checkmark$ & & & & & p3 & 0.2 \\
\hline G23 & & & $\checkmark$ & & & & & p3 & 0.2 \\
\hline G24 & & & $\sqrt{ }$ & & & & & p3 & 0.2 \\
\hline G25 & & & $\sqrt{ }$ & & & & & p3 & 0.2 \\
\hline $\mathrm{G} 26$ & & & & $\sqrt{ }$ & & & & p4 & 0.3 \\
\hline G27 & & & & $\checkmark$ & & & & p4 & 0.3 \\
\hline G28 & & & & & $\checkmark$ & $\checkmark$ & & P5,p6 & 0.4 \\
\hline G29 & & & & & $\checkmark$ & & & p5 & 0.2 \\
\hline G30 & & & & & & & $\sqrt{ }$ & $\mathrm{p} 7$ & 0.3 \\
\hline
\end{tabular}

Can be seen from the table above Symptom relations and digestive system disorders in humans and the results of the final value as in the table above which shows the disease code P1 and the symptom code G1 with the results of calculation 0.2 using the Dempster Shafer method.

A. Calculation of Algorithms with the Dempster Shafer method

The following sample for solving problems with the Dempster-Shafer calculation method. It is known that the symptoms of disease in the human digestive system are as follows:

\section{Chest pain.}

This symptom is caused by stomach acid disease. The value of the density determined by the expert from these symptoms is

$\mathrm{m} 1(\mathrm{P} 1)$ is $80 \%=0.8$

Then the value of believe $\mathrm{m} 1\{\theta\}=1-0.8=0.2$

\section{The body feels weak}

This symptom is caused by chronic diseases and diarrhea.

The value of the density determined by the expert from these symptoms is

$\mathrm{m} 2(\mathrm{P} 1, \mathrm{P} 4)$ is $60 \%=0.6$

Then the value of believe $\mathrm{m} 2\{\theta\}=1-0.6=0.4$ Then the combination value rule for the $\mathrm{m} 3$ trust value is as follows.
Table 4. Calculation of symptoms to $1 \& 2$

\begin{tabular}{|c|c|c|}
\hline \multirow{2}{*}{$\mathrm{m} 1$} & \multicolumn{2}{|c|}{$\mathrm{m} 2$} \\
\cline { 2 - 3 } & $\mathrm{P} 1, \mathrm{P} 4(0,6)$ & $\theta(0,4)$ \\
\hline $\mathrm{P} 1(0,8)$ & $\mathrm{P} 1, \mathrm{P} 4(0,48)$ & $\mathrm{P} 1(0,32)$ \\
\hline$\theta(0,2)$ & $\mathrm{P} 1, \mathrm{P} 4(0,12)$ & $\theta(0,08)$ \\
\hline
\end{tabular}

Information :

By using a combination formula like the following. $\mathrm{m} 1 \oplus \mathrm{m} 2$

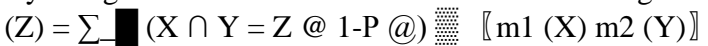

So that it can be calculated:

$\mathrm{m} 3\{\mathrm{P} 1\}=0.32 /(1-0)=0.32$

$\mathrm{m} 3\{\mathrm{P} 4\}=(0.48+0.12) /(1-0)=0.6$

$\mathrm{m} 3\{\theta\}=0.08 /(1-0)=0.08$

Feel cramps in the stomach

This symptom is caused by inflammatory bowel disease.

The value of the density determined by the expert from these symptoms is

$\mathrm{m} 3(\mathrm{P} 5)$ is $70 \%=0.7$

Then the believe value of $\mathrm{m} 4\{\theta\}=1-0.7=0.3$ Then the combination rule for the trust value $\mathrm{m} 5$ is as follows.

Then the combination value rules for the $\mathrm{m} 5$ trust value are as follows.

Table 5. 3rd symptom calculation

\begin{tabular}{|c|c|c|}
\hline \multirow{2}{*}{$\mathrm{m} 3$} & \multicolumn{2}{|c|}{$\mathrm{m} 4$} \\
\cline { 2 - 3 } & P5 $(0,7)$ & $\theta(0,3)$ \\
\hline P1,P4 $(0,6)$ & P5 $(0,42)$ & P1,P4 $(0,18)$ \\
\hline P1 $(0,32)$ & P5 $(0,224)$ & P1 $(0,096)$ \\
\hline$\theta(0,08)$ & P5 $(0,056)$ & $\theta(0,024)$ \\
\hline
\end{tabular}

$\theta(0,08)$ P5 $(0,056) \theta(0,024)$

Information :

By using a combination formula such as $\mathrm{m} 3$ as follows.

$\mathrm{m} 1 \oplus \mathrm{m} 2(\mathrm{Z})=\sum \square(\mathrm{X} \cap \mathrm{Y}=\mathrm{Z} @ 1-\mathrm{P} @)$ 䨽】

$\mathrm{m} 1(\mathrm{X}) \mathrm{m} 2(\mathrm{Y}) \rrbracket$

So that it can be calculated:

$\mathrm{m} 3\{\mathrm{P} 4\}=0.18 /(1-0)=0.18$

$\mathrm{m} 3\{\mathrm{P} 1\}=0.096 /(1-0)=0.6$

$\mathrm{m} 3\{\mathrm{P} 5\}=(0.42+0.224+0.056) /(1-0)=0.7$

$\mathrm{m} 3\{\theta\}=0.024 /(1-0)=0.024$

From the results of this combination with the highest density in Intestinal Inflammatory Disease (P5), it can be concluded that the disease occurs in the intestine.

This manual calculation is also done using the Certainty Factor method.

The following sample for completion of calculations with the Certainty Factor method. Percentage of confidence calculation 
begins with solving a rule that has multiple symptoms, becoming rules that have a single symptom. Then each CF rule is calculated using equation 2.2 :

Rule 1:

IF Pain in the chest (G1)

AND Pain When Swallowing (G2) AND Dry Cough (G5)

AND Heartburn (G11) THEN Gastric Acid Disease

$\mathrm{CF}$ value for symptom experts (Value determined by expert):

Expert $\mathrm{CF}(\mathrm{G} 1)=0.4 \mathrm{CF}$ expert $(\mathrm{G} 2)=0.7 \mathrm{CF}$ expert $(\mathrm{G} 5)=$ $0.7 \mathrm{CF}$ expert $(\mathrm{G} 11)=0.6$

The user selects the answer

Symptoms (G1): (Yes) Enough Sure $=0.6$ Symptoms $(\mathrm{G} 2)$ : (Yes) Not Sure $=0.2$ Symptoms (G1): (Yes) Sure $=0.8$

Symptoms (G11): (Yes) Slightly Confident $=0.4$

Code 1.1: IF Pain in the chest (G1) THEN Gastric Acid Disease.

Rule 1.2: IF Pain when swallowing (G2) THEN Gastric Acid Disease.

Rule 1.3: IF Dry Cough (G5) THEN Gastric Acid Disease.

Code 1.4: IF Heartburn (G11) THEN Gastric Acid Disease.

Calculation Process:

CF (G1): CF (User) * CF (Expert)

: $0.6 * 0.4=0.240$

$\mathrm{CF}(\mathrm{G} 2)$ : CF (User) * CF (Expert)

$: 0.2 * 0.7=0.140$

$\mathrm{CF}$ (G5): CF (User) * CF (Expert)

: $0.8 * 0.7=0.560$

$\mathrm{CF}$ (G11): CF (User) * CF (Expert)

$: 0.4 * 0.6=0.240$

CFCombine1 (CF G1, CF G2): CFG1 + CFG2 * (1- CFG1)

$: 0,240+0,140 *(1-0,240)$

CF Old 1: 0,289

CFCombine2 (Old CF 1, CF G5): CFOld1 + CFG5 * (1-CF Old1)

$: 0.289+0.560 *(1-0,289)$

Old CF 2: 0.604

CFCombine3 (Old CF1, CF G5): CFOld2 + CFG11

* (1-CF Old2)

$: 0.604+0.240 *(1-0,604)$

Old CF 3: 0.334

In the picture below is a system flowchart for analyzing the symptoms of Dempster Shafer's disease.

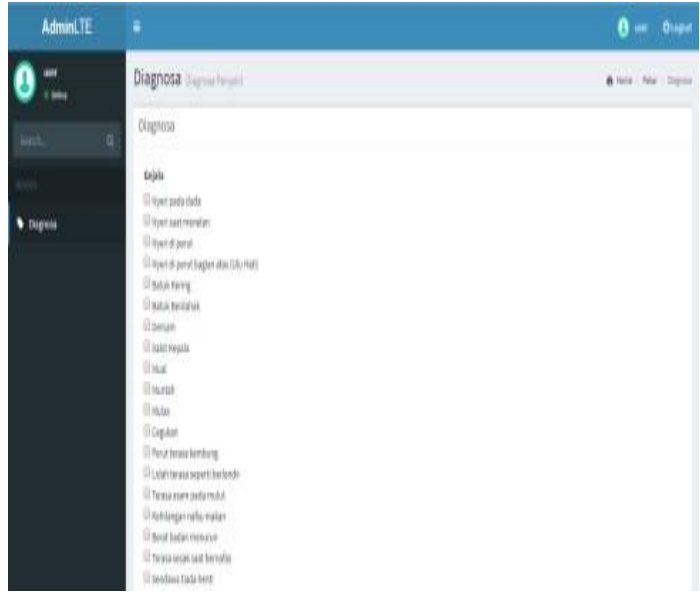

Figure 4 Page Diagnosis

In Figure 4 above shows the form for users to choose symptoms, which will be the data to be calculated to display the diagnosis of digestive system disorders in humans.

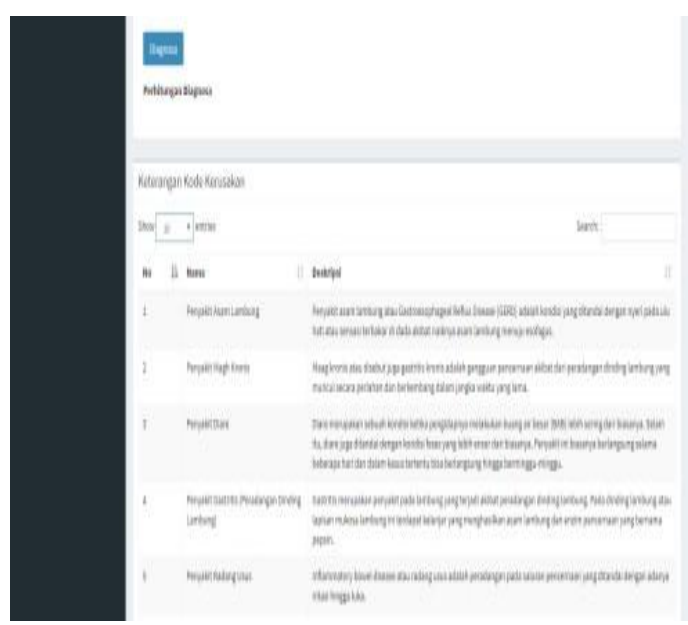

Figure 5 Description of Disease Page

In Figure 5 above shows a list of diseases of the digestive system, can change and delete data.

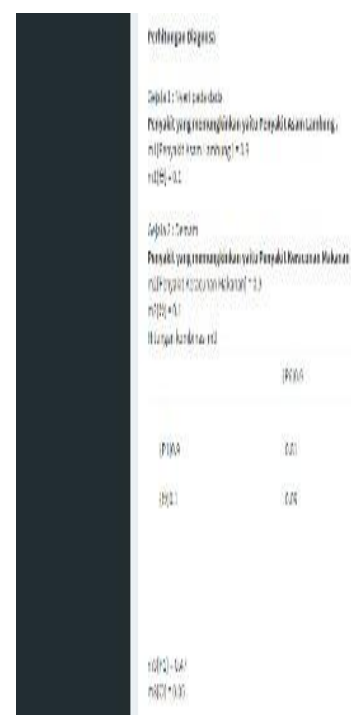

Figure 6 Diagnosis Calculation Results Page 
In figure 6 displays the results of the diagnosis that has been done in the previous process, which includes some symptoms of the disease.

\section{CONCLUSION}

Based on the results of the research and analysis of the results of the research that has been carried out, by applying the calculation of the Dempster Shafer Method and Certainty Factor to diagnose digestive system disease in humans, some conclusions can be drawn as follows. Based on the results of calculations above, it can be seen that the Dempster Shafer Method is the method that has the highest value with $70 \%$ confidence compared to the Certainty Factor Method with a value of $60 \%$. Based on the above calculation values, later the implementation of the Expert System to diagnose digestivesystem disease in humans is to use the Dempster Shafer Method. The amount of the calculation of the density of each possible disease obtained from the Dempster Shafer Method is

1. With the highest density value is the most likely possibility or the closest to the diagnosis of the disease.

\section{ACKNOWLEDGMENT}

This research was held on funds from national universities, namely competitive research in 2018 . This research was the of collaboration between lecturers and final year students.

\section{REFERENCES}

[1] A Triayudi, AZ Nazori. 2012. Teacher Performance Assessment System Analysis Using Mamdani's Fuzzy Inference System: Case Study of UPT Education Office Kec. Penengahan South Lampung.

[2] A Triayudi, V Rosalina. 2019. Electronic Customer Relationship Management (E-CRM) Application as Efforts to Increase Customer Retention of Micro Small and Medium Enterprises (MSMEs) in Banten Indonesia.

[3] Amanda Patria, Putra. \& Cahya Rahmad.2015. Comparative Analysis of Certainty Factor with Dempster Shafer Method in Melituspolinema Diabetes Diagnosis Expert System.Kusumadewi, S. Artificial Intelligence (Techniques and Applications). 2003. Graha Ilmu. Yogyakarta.
[4] Ricky Hamidi, et al. 2017. Comparative Analysis of Expert Systems with Certainty Factor Method and Dempster Shafer Method in Rabbit Disease.

[5] Giarratano, J., Riley G. Expert Systems. 2005. (Principles and Programming). PWS Publishing Company. Boston.

[6] Kusrini. Expert System (Theory and Application). Andi Offset. Yogyakarta. 2006.

[7] Kusrini. Expert System Application. Andi Offset Yogyakarta. 2008

[8] Wahyuni Gustri, Elyza \& Prijodiprojo, Widodo. (2013). Expert System Prototype for Detecting the Risk Level of Coronary Heart Disease with the Dempster-Shafer Method. Yogyakarta: UGM University.

[9] Triara Puspitasari. (2016). Implementation of the Dempster Shaffer Method in the Web-Based TunaGrahita Child Diagnosis Expert System. Vol.1 No.1 March 2016. Bengkulu: University of Bengkul

[10] Sembiring $\mathrm{Br}$ Sari, Nita \& Sinaga Dayan, Mikha. Application of the Dempster Shafer Method to Diagnose Disease from the Effects of Treponema Pallidum Bacteria. CSRID Journal, Vol.9 No.3 October 2017.

[11] Loai Zomlot, et al. (2013). Poster: Prioritizing Instrusion Analysis Using Dempster-Shafer Theory. Kansas State University.

[12] Hustinawaty, R. A. (2014). The Development of Web Based Expert System for Diagnosing Children DiseaseUsing Php and Mysql. International Journal of Computer Science \& Information Technology, 4 (5), 175.

[13] J.A, Barnett, "Computational methods for a mathematical theory of evidence", Proc. 7th International Joint Conference on Artificial Intelligence (IJCAI), Vancouver, vol. II, pp. 868-875, 1981.

[14] Tomasz Neumam, Adam Weintrit. (2012). Expert system based on Dempster Shafer theory of evidence in maritime-charcteristic applications. Gdynia Maritime University 32 (104) z. 2pp. 141-137 